\title{
主題別抄録誌
}

付 : 二次資料欄を持つ雑誌リスト

\section{Medical Abstracts Services}

要 約

主題別抄録誌で, 国内に数館以上の所藏のあるもの 27 誌について紹介した。内容は, 創刊年, 主題領域, 記载 事項などの他，収載誌りストを持っているものに関して は，IM， EM とのオーバーラップを調査し，その抄録 誌にしか収載されていないるのの比率を示した。付表と して，打もな二次資料欄を持つ雑誌のリストをつけた。

\section{は じめに}

本文では，特定主題領域を扣もにとり扱っている抄録 誌の紹介を行う。並べ方は, 大まかな主題のもとで, 抄 録誌名のアルファベット順とした。抄録誌名はゴヂック で示している。内容の紹介は以下の順で行なっている。 (1)出版社 (者), 又は編者, 場合によっては, その両者。 (2)創刊年，括よび誌名変更のあったものは，旧誌名。(3) 発行頻度。(4)とり扱っている主題領域。(5)単行書, 会議 録などの収載の有無。(6)収載件数。㹺もに, 1973 年と 1974 年の収載件数を記した。(7)タイムラグ。算出方法 は, 抄録誌の各号に示された発行年月と, 抄録されている 文献の揭載された雑誌に示された発行年月との差とし, 月を単位として記した。(8)報知的抄録であるか，指示的 抄録であるかを記した。(9)著者抄録であるか，第 3 者抄 録であるか，わかるかぎり記した。(10索引の付き方。a） は各号に付く索引の種類。b) は巻に付く索引の種類, 別 冊か否か, 発行の遲れ，などを記した。(11)収載誌。a) は 収载誌数,またそのうちの国内誌数を記した。b) は Index Medicus (IM) および Excerpta Medica (EM) との収載の重なり具合を記した。数字は，その抄録誌に

* Naohiko YAMAGUCHI : Osaka University Nakanoshima Library

\section{山口直比古* 大阪大学附属図書館中之島分館}

のみ収載されている雑誌数，（全収载誌中の占めるパー セント), IM に収載されている雑誌数, (そのパーセン ト), EM に収載されている雑誌数，(そのパーセント), IM，EM の両方に収載されている雑誌数，(そのパーセ ント)をそれぞれ示している。c）は収載誌リストの有 無, 揭載される場所, 内容などを記した。(12) 記載事項。 （）は注釈，[ ]は有る場合と無い場合のあるもの，／ は段落を示している。傕誌名の省略の仕方, 例郎ば IM による，などの注のあるものもあったが，本文では省い た。113 その他，特筆すべき事項を，ここに記した。

\section{Anatomy}

\section{Calcified Tissue Abstracts}

(1) Information Retrieval Publication (2) 1969 年 (3) 月刊 (4)骨組織, 結合組織などの構造, 機能, 代謝。関 連微生物学, 及び, ホルモン, 酵素学など。(5)単行書会 議録を収載。(6) 1973 年 2,573 件, 1974 年 2,777 件 (7) 2 10 か月 (8)報知的抄録 (9)著者抄録がある場合は, 優 先的に採用している。(10) a) 著者, b) 著者, 12 号に揭 載 (11) a) 3, 738 誌, b) 2, $143(57.33 \%), 390$ (10.43\%), $284(7.59 \%), 921(24.63 \%)$ c) 年に 1 度特定号に揭載 される,フルタイトルのみ。(12)抄録番号 (5 CT ***; Calcified Tissue Abst. の 5 巻の意), 英文タイトル, [オリジナル・タイトル], 著者, 雑誌名巻, 号, 頁 (始 一終), 年, 所属, 本文, 本文和上び抄録の言語, (13) IRL からは，他に 15 種の抄録誌が出版されている。本文で もいくつか絡介している。収載誌は全ての抄録誌に共通 である。

\section{Biology and Microbiology}

\section{Biological Membrane Abstracts}

(1) Information Retrieval Publication (2) 1973 年 (3) 
月刊 (1)膜組織の形態, 機能, 構造 (5)単行書，会議録を 収載 (6) 1973 年 5,075 件, 1974 年 3,577 件 (7) 4 〜 月 (8)報知的抄録 (9著者抄録がある場合は優先的に採用 している (10)a) 著者，b) 著者，12 号揭載 (11) a) 3, 738 誌 b) $2,143(57.33 \%), 390(10.43 \%), 284(7.59 \%)$, $921(24.63 \%)$ c) 年に 1 度特定号に揭载される。フル タイトルのみ。(12) 抄録番号 $(2 \mathrm{M}$ ***; Biol. Memb. Abst. の 2 巻の意), 英文タイトル, [オリジナル・タイ トル], 著者, 雑誌名, 巻, 号, 頁 (始一終), 年, 所属, 本文，本文抢よび抄録の言語 (12) IRL からは，他に 15 種の抄録誌が出版されている。本文でもいくつか紹介し ている。収載誌は全ての抄録誌に共通である。

\section{Genetics Abstracts}

(1) Information Retrieval Publication (2) 1968 年 (3) 月刊 (4)微生物・㲜植物・人間に関する 遺伝学及びその 関連領域 (5)単行書, 会議録を収载 (6) 1973 年 14, 324 件, 1974 年 12,615 件 (7) 5 ～9 月 (8)報知的抄録 (9)著者抄 録のある場合は優先的に採用している (10) a) 著者 b) 著 者, 12 号に掲載 (11) a) 3, 738 誌 b) 2, 143 (57.33\%), $390(10.43 \%), 284(7.59 \%), 921(24.63 \%), c)$ 年に 1 度特定号に揭載される。フルタイトルのみ，(12抄録番 号, 英文タイトル, [オリジナル・タイトル], 著者, 雑 誌名, 卷, 号, 頁 (始一終), 年, 所属, 本文, 本文就上 び抄録の言語 (13) IRL からは, 他に 15 種の抄録誌が出 版されている。本文でもいくつか紹介している。収哉誌 は全ての抄録誌に共通である。

\section{Microbiology Abstracts}

sect. A Industrial and Applied Microbiology

(1) Information Retrieval Publication (2) 1965 年 (3) 月刊 (4)真菌, ウイルス,バクテリアなどの応用微生物学 (5)単行書, 会議録, 特許を収載 (6) 1973 年 8, 753 件 1974 年 7,838 件。

\section{sect. B Bacteriology}

(2) 1966 年 (3月刊 (4)バクテリアに起因する疾病の疫 学，免疫学など。家畜の流行病なども含む (5)単行書, 会議録を収載 (6) 1973 年 11, 454 件, 1974 年 11, 335 件

sect. C Algology, Mycology, Protozoology

(2) 1972年 (3)月刊 (4)藻類, 菌類, 原生動物飞関して sect. A で扱う以外のもの (Non Industrial Scope) (5)単行 書, 会議録を含吉 (6) 1973 年 8, 508 件, 1974 年 7, 130 件 sect. $\mathrm{A}, \mathrm{B}, \mathrm{C}$

(8)報知的抄録，(9著者抄録のある場合は優先して採用 (10) a) sect. A 著者 sect. B 著者, Species Index sect.
C 著者, Species Index b) sect. A 著者, Patentee \& Assignee Index sect. B 著者 sect. C 著者 (11) a) 3, 738 誌 b) 2, 143 (57.33\%), 390 (10.43\%), 284 (7.59\%), $921(24.63 \%)$ c) 年に 1 度特定号に揭載。フルタイト ル (12)抄録番号, 英文タイトル, [オリジルナ・タイトル], 著者, 雑誌名, 巻, 号, 貣 (始一終), 年, 所属, 本文, 本 文特よび抄録の言語 (13) IRL からは他に 15 種の抄録誌 が出版されている。本文でもいくつか紹介している。収 載誌は全ての抄録誌儿共通である。

\section{Virology Abstracts}

(1) Information Retrieval Publication (2) 1967 年 (3) 月刊 (4)ウイルスによる感染症, 腫瘍学, 及び抗生物質 など (5)単行書, 会議録を収戴 (6) 1973 年 7,067 件, 1974 年 7,138 件 (7) 2 10 只月 (8) 報知的抄録 (9) 著者抄録の 西る場合は優先して採用 (10) a) 著者, Index to Viruses b) 著者, 12 号に揭載 (11) a) 3, 738 誌 b) 2, 143 (57.33 \%), 390 (10.43\%), 284 (7.59\%), $921(24.63 \%)$ c) 年に 1 度特定号に揭載, フルタイトル (12)抄録番号, 英文 タイトル, [オリジナル・タイトル $]$, 著者, 雑誌名, 巻, 号, 頁 (始一終), 年, 所属, 本文, 本文和よび抄録の言 語 (13) IRL からは，他に15 種の抄録誌が出版されてい る。本文でもいくつか紹介している。収載誌は全ての抄 録誌に共通である。

\section{Chemistry and Biochemistry}

\section{Amino-acid and Protein Abstracts}

(1) Information Retrieval Publication (2) 1972 年 (3) 月刊 (4)アミノ酸, ペプチド, タンパク質のX線,電顕な ぞによる構造・状態，合成など，および関連する蹼素・ ホルモンなど (5)単行書，会議録を収載 (6) 1973 年 7,652 件 1974年 8,281 件 (7) 2 7 7 月 (8) 報知的抄録 (9)著 者抄録がある場合は優先して採用 (10) a) 著者, Peptide and Protein Index b) 著者, Pepteide and Protein Index 12 号に揭載 (11) a) 3, 738 誌 b) 2, 143 (57.33\%), $390(10.43 \%), 284(7.59 \%), 921(24.63 \%)$ c) 年に 1 度特定号に揭哉, フルタイトル (12)抄録番号, 英文タイ トル, [オリジナル・タイトル], 著者, 䧴誌名, 巻, 号, 頁 (始一終)，年，所属本文，本文拉よび抄録の言語 (13) IRL からは他に 15 種の抄録誌が出版されている。本文 でもいくつか紹介している。収載誌は全ての抄録誌に共 通である。

Current Abstracts of Chemistry and Index Chemicus 
(1) ISI (2) 1969 年 (3)週刊 (4)化学物質の合成・分離特 よび，新化合物，新たな反応など，新規性の高い化合物 飞関する文献が中心 (6) 1973 年 13, 356 件 1974 年 12, 687 件 (化合物数 147, 950 種) (7) $2 \sim 4$ か月 (8)指示的抄録, 化学反応式, 满造式（抄録のないものも多い）(10) a) 都 者, 主題, Molecular Formula Index $\left(\mathrm{C}_{\mathrm{n}} \mathrm{H}_{\mathrm{m}}\right.$ の順), Corporate Index b) Quarterly Index (Volume Index) Issue Index と同じ, Annual Index, Issue Index 々同 じ, 他に Journal Index, Rotaform Index ( $, \mathrm{H}, \mathrm{N}, \mathrm{O}$, 以外の物質からの索引) (11) a) 120 誌, 化学の他, 薬学・ 生化学を含み,レタ一誌も收載 b) 化学関連領域の core な雑誌のみを収载しているので,とりわけ CA には全て 収載されている (12)抄録番号, タイトル, 著者, 所属, 雑 誌名, 年, 巻, 頁 (始一終), 本文 (化学反応式, 構造 式）(13この抄録誌は非常にニニークな抄録誌である。化 学関係の core な journal から, 化合物の生成, 反応な ぞを扱った論文のらち新規性の高いものを抽出し反応式 や掅造式を揭載している。速報性核重点を和いている事 がうかがえる。また，その文献がぞのような方法を用い た実験を報告しているかが，一目でわかる円形のシグナ ルが党がかれている。例光ば，その項目としてはNEWRXN (新反応), UV (Ultra Violet), NMR (Nuclear Magnetic Resonance), GC (Gas Chrom atography), TLC (Thinlay Chromatography) などがあり, 該当項 目がチェックされているのである。抄録は，雑誌名のる とに，その号に揭載されている文献があつめられてい る。従って，目次は，この雑誌名の目次となるが，他に Labeled Compounds, New Syntheses, New Reactions の目次がある。

\section{Dentistry}

\section{Dental Abstracts}

(1) American Dental Association (2) 1956 年 (3)月刊 (4)歯学 (6) 1974 年拈上そ 1,000 件 (7) 6 9 か月 (8)報知 的抄録 (9)第 3 者抄録が多い (10) a) なし b) 著者, 主題 (i1) a) 181 誌 米・加の歯科医師会誌が中心 b) $81(44.75$ \%), 28 (15.46\%), $13(7.18 \%), 59(32.59 \%)$ c) 12 号に揭載, 略誌名, 完全誌名, 出版地 (12)内容を示寸数語 の見出し / 本文, 著者, 所属, 住所, 雑誌名, 巻, 頁 (始 一終) 月, 年 (10)每号 Special Articles といら欄で, 1 件 程度かなりくわしく文献を紹介している。その他, News 欄，新製品欄，時には専門的なクイズをのせたクイズ闌 などがある。

\section{Oral Research Absîracts}

(1)American Dental Association (2) 1966年 (3)月刊 (4)歯科専門領域の他, 教育, 歷史, 社会学などのセクシ ヨンも㐫る (5)特許情報を含む (6) 1973 年 7, 514 件 1974 年 7,674 件 (7) 12 18 只 (8)報知的抄録 (9)第 3 者抄録 が多い (10) a) 著者 b) 著者, 主題, Patent Concordance 別冊でおよそ6か月遲れる (11) a) 873 誌 b) 253 (28.98 \%), $95(10.88 \%), 104(11.91 \%), 421(48.22 \%)$ c) Index vol. 飞掲載される。略誌名, 完全誌名, 出版地 (12)抄録番号, タイトル, 著者, 所属, 雑誌名, 巻, 号, 頁 (始一終), 月, 年, 本文, 抄録者名 (13)同じく $\mathrm{ADA}$ から出版されている Dental Abstracts と比較すると, 次のような事がいえる。DA は速報性はあるが網羅性で は ORA に劣る。抄録の内容では DA の方が詳しい。

\section{Dermatology}

Zentralblatt für Haut- und Geschlechtskrankheiten sowie deren Grenzgebiete. Abstract section of Archiv für Dermatologische Forschung.

(1) Springer-Verlag (2) 1921 年 (3)年にほぼ 1 巻 9 冊, 9 冊目は Index (5)単行書を収載（印が付いて各セク ションの最初にくる) (6 132 巻（1974 年) 3,185 件 (7) 12 18 か月 (8)報知的抄録 (9第 3 者抄録が多い (10) a) 著者 b) 著者, 主題, 9 号が Index で発行は拈上そ 8 か 月遅れる (111) a) 1, 140 誌うち国内誌は 69 誌 b) 222 (19.47\%), 120 (10.52\%), $197(17.28 \%), 601(62.71$ \%) c）1971 年に収載誌りストが出版された，国別完全 誌名 (12抄録番号, タイトル, 著者, 所属, 雑誌名, 巻, 頁 (始一終), 年, 本文の言語 / 本文 (独語), 抄録者名 (13) Springer からは他に13 種の抄録誌が出版されてい る。本文でもいくつか紹介している。

\section{Digestive System}

\section{Gastroenterological Abstracts and Citations}

(1) National Institute of Arthritis, Metabolism and Digestive Diseases (2) 1966 年 (3)月刊 (4)胃腸疾患打上 びその治療, 病理など (6) 1973 年 8, 237 件, 1974 年 9, 691 件 (7) 1 3 3月と短いが, 発行が拈上そ8 か月遅れてい る。(8)報知的抄録であるが，抄録の付されているのは全 体の 3 分の 1 程度であり, 他はタイトルの引用のみ (10) a) 著者, 主題 b) 著者, 主題, 別冊であるが出版は僬れ ない（11)収載誌リストなし（12)抄録番号，英文タイトル， 言語, 著者, 所属, 雑誌名, 巻, 号, 頁 (始一終), 年, 本文。 


\section{Neoplasms}

\section{Cancer Therapy Abstracts}

(1) National Cancer Institute, Hernar Information Service Inc. (2) 1960 年 1960 74 ; Cancer Chemotherapy Abstracts (3)月刊 (4)癌の放射線潦法, 免疫療法な ど治療に関したもの (5)単行書を収載している (6) 14 巻 （1973 74 年) 3,331 件 15 巻（1974 75 年) 5,439 件 (8) 報知的抄録 (9)第 3 者抄録(抄録作業は Franklin Institute Research Laboratory のメンバーによっている) (10) a) 著者, 主題 b) 著者, 主題, 別冊 (11)医学の他に, 公害関 係, 数学, コンピューター・サイェンスも含んでいる。 収載誌は不明, Franklin Institute の所蔵によっている。 (13)抄録番号, タイトル, 言語, 著者, 所属, [第 2 以下の 著者], 雑誌名, 巻, 号, 頁 (始一終), 年/本文, 参照 文献の数 (13) 13 巻（1972 73 年) より MT によるデー タベース化が行なわれて拈り，CANCERLINE によっ て検索できる。

\section{Carcinogenesis Abstracts}

(1) National Cancer Institute, Franklin Institute Research Laboratory (2) 1963 年 (3)月刊 (4)癌の発生に関 乙, 化学的,物理的に，また免疫学・ウイルス学などの面 からあつかっている (6) 11 巻 (1972 73 年) 7, 200 件, 各 号 600 件程度で，そのらち半数には抄録が付されていな い (8)報知的抄録 (9)第 3 者抄録（抄録作業には Franklin Institute Research Laboratory のメンバーがあたって (いる）(10 a) 著者, 主題 b) 著者, 主題, 別冊 (11)収載 誌は不明, Franklin Institute の所蔵による (13)抄録番号, タイトル, 言語, 著者, 所属, [第 2 以下の著者], 雑誌 名, 巻, 号, 頁 (始一終), 年/本文, 参照文献の数 (13) CANCERLINE で検索できる。

\section{Leukemia Abstracts}

(1) The Lenore Schwartz Leukemia Research Foundation, Research Information Service The John Crerar Library (2) 1953 年 (3)月刊 (4)白血病および関連領域 (6) 1973 年 1,376 件 1974 年 1,377 件 (7) $3 \sim 6$ か月 (8)報知的 ではあるが比較的短い (9) Dissertation Abstracts International からも収載している (10) a) b) ともになし (11) 収載誌リストなし，John Crerar Library 所蔵のもの (12抄録番号，英文タイトル，言語，著者，所属，雑誌名， 巻, 号, 頁 (始一終), 月, 年/本文, 参照文献 (13)無 料, 請求先, The John Crerar Library, 35west 33rd Street, Chicago, Illinois, 60616 U.S. A.

\section{Nutrition}

\section{Nutrition Abstracts and Reviews}

(1) Commonwealth Bureau of Nutrition (2) 1981 年 (3)月刊 (4)栄美学, 食品科学, ビタミン, 酵素, 脂質, そ の他食飼療法，動物飼育なども含む (5)単行書，会議録 Report 類を収載している (6) 1973 年 8,685 件, 1974 年 8,465 件 (7) 12 18 か月 (8)報知的抄録 (9)著者, 第 3 者 抄録が半々程度 (10) a) 著者, 主題 b) 著者, 主題, 別冊 で 6 ケ月以上刊行が遅れる (11)収載誌リストなし，(12)抄 録番号, 著者, 英文タイトル, [オリジナル・タイトル], 雑誌名, 年, 巻, 号, 頁 (始一終), 言語, 所属 / 本文, 抄 録者名 (13)年に $1 \sim 2$ 度 Review Article が揭載される。

\section{Ophthalmology}

\section{Ophthalmic Literature}

(1) British Medical Association (2) 1947 (3)季刊 (4)疾 病の他に生理学, 病理学的な要素も含む (5)単行書を収載 乙ている (6) 1973 年 6,585 件 (7)6 12 か月 (8)報知的抄 録であるが比較的短い (9)第 3 者抄録が多い (10) a) 著者, b) 著者, 主題, 別冊, 1 年以上発行が湦れる (12) 抄録番 号, 英文タイトル，言語，著者，雑誌名，巻，頁 (始一 終)，号，年，本文，抄録者名 (13) Am. J. Ophth. との 抄録の交換を行っている。

\section{Otolaryngology}

\section{S. H. Abstracts}

(1) Deafness Speech and Hearing Publication Inc. (2) 1960 年 (3)季刊 (4) Speech and Hearing Disorder (5)単行書，政府刊行物を収載している (6) 1974 年 3,236 件 (8)報知的抄録 (9)著者抄録が多い（10) a) 著者 b) 著者 主題，4号に揭載 (11) 399 誌うち国内誌 12 誌 b) 181 (45.36\%), 36 (9.02\%), 53 (13.28\%), 129 (32.33\%) c) 4 号に掲載, 完全誌名, 略誌名, 出版地国名 (12)抄録番 号, 著者, 所属, オリジナル・タイトル，[英文タイト ル], 雑誌名, 巻, 号, 年, 頁 (始一終) / 本文, 参照文 献の数, 抄録者名（著者抄録の場合は J. Abst. と, また 他の抄録誌からの転載の場合はその抄録誌名が記載され ている) (13) Abst. Soc. Works, Oral Res. Abst, Psychol. Abst. など15の抄録誌からも，抄録を転載している。

Zentralblatt für Hals-, Nasen- und Ohrenheilkunde sowie deren Grenzgebiete

(1) Springer, Organ der Deutschen Gesellschaft für Hals-, Nasen- Ohrenhilkunde, Korp- und Halschirurgie 
(2) 1922 年 (3) 2 年で 3 巻程度, 1 巻 6 冊で 6 冊目は Index (5)単行書を収载（・印を付して各セクションの最初にき ている）（6) 108 巻（1974年) 2,444 件 109 巻 (1974 75 年) 2,451 件 (7) $12 \sim 18$ 只月 (8)報知的抄録 (9)第 3 者抄 録が多い(10) a) 著者，b）著者, 主題, 出版が 1 年程度 遅れる (11) 720 誌，らち国内誌 34 誌 b) 117 (16.25\%), 86 (11.94\%), 119 (16.52\%), 398 (55.27\%) c) 1971 年に収載誌リストが出版された。完全誌名, 国別 (12)抄録 番号, 独語タイトル，[オリジナル・タイトル，著者, 所属, 雑誌名, 巻, 頁 (始一終) 年, 本文(独語), 抄録 者名 (13) Springer からは他に 13 誌の抄録誌が出版され ている。本文でもいくつかを紹介している。

\section{Pathology}

Berichte über die allgemeine und spezielle Pathologie.

(1) Springer (2) 1948 年 (3)年間 $1 \sim 2$ 巻, 1 巻は 6 冊 で 6 冊目は Index (4)病理学, ただし 22 巻以降, 各巻 1 号 は Geschwulstforschung（潰瘍学）を特集している (5) 単行書を収載している（⿴印を付して各セクションの最 初にきている) (6) 86 巻 (1974 年) 1,885 件 87 巻 (1974 ７5 年) 1,882 件 (7) 16 22 分月 (8)報知的抄録, (9)第 3 者抄録が多い（10 a) 著者 b) 著者，主題，出版はほぼ 1 年遅れる (11) a） 1,115 誌，うち国内誌は 60 誌 b) 185 (16.59\%), 109 (9.77\%), 165 (14.79\%), 656 (58.83 \%）c） 1971 年に収載誌リストが出版された国別リスト (12)抄録番号，独文タイトル，[オリジナル・タイトル], 著者, 所属, 雑誌名, 巻, 頁 (始一終)，年，本文 (独 語)，抄録者名 (13) Springer からは他に 13 誌の抄録誌が 出版されている。本文でもいくつか紹介している。これ らは延べで 2,368 誌をカバーしている。

\section{Pediatrics}

\section{Zentralblatt für gesamte Kingerheilkunde}

(1) Springer, Referatenorgan der Deutschen Gesellschaft für Kinderheilkunde (2) 1911 年 (3)年打よそ 1 巻 6 冊, 6 冊目は Index (4)小児科学 (5)単行書を収載して いる（印を付して各セクションの最初にきている）(6) 114 巻（1974 年) 2,296 件 115 巻 (1974 75 年) 2,222 件 (7) 13 19 か月 (8)報知的抄録 (9)第 3 者抄録が多い (10) a) 著者 b) 著者，主題，出版は 2 年近く遅れる (11) a) 952 誌，うち国内誌は 49 誌 b) 144 (15.12\%)，111 (11.65 \%)，162(17.01\%)，535(56.19\%）c） 1971 年に収載 誌リストが出版された，国別リスト (12)抄録番号，独文
タイトル, [オリジナル・タイトル], 著者, 所属, 雑誌 名, 巻, 頁 (始一終), 年, 本文 (独語), 抄録者名 (13) Springer からは他に 13 誌の抄録誌を出版している。本 文でもいくのか紹介している。これらは，延べで 2,368 誌をカバーしている。

\section{Pharmacology}

\section{International Pharmaceutical Abstracts}

(1) American Society for Hosiptal Pharmacists (2) 1964 年 (3)半月刊 (4)薬理学, 薬剤学, 毒物学などの他に, 歴史，社会学，経済学などの分野からも関連するものを ひろっている。(6) 1974 年 5,062 件 (7)英語文献 6 10 か 月, 英語以外の文献 12 24 か月 (8)報知的抄録 (9)著者抄 録，第 3 者抄録の他に Modified Author Abstract があ る (10) a) 主題 b) Semiannual Index 著者, 主題, 各巻 の 12 号と 24 号 (11) a) 928 誌 b) 343 (36.96\%), 119 (12.82\%), $163(17.56 \%), 303(32.65 \%)$, c) 各巻 1 号に掲載, 略誌名, CODEN, 完全誌名, 出版地 (12)抄録 番号, タイトル, 著者, 所属, 雑誌名, 巻, 頁(始一終), 月, 年, 言語 / 要旨がゴヂック体で記してある，本文， 参照文献の数 / 抄録者名 (13)付録として, IPAの 25 の七 クションの解説，化合物命名法の解説，そして各巻 1 号， 12 号，24号には Guide to Use of Index がある。

\section{Psychopharmacology Abstracts}

(1) National Clearinghouse for Mental Health Information (2) 1961 年 (3)月刊 (4)精神薬理学 (5) NIMH のレポート類を多く収載している (6) 1971 年 2, 500 件程 度 (7) 10 15 か月 (8)報知的抄録 (9)著者抄録と Modified Author Abstract が多い (10) a) 著者, 主題 (KWOC) b) 著者, 主題, 別冊，(11)収載誌リストなし (12)抄録番号 (1 連番号ではない, 意味は不明), 著者, 所属, タイトル, 雑誌名, 巻, 号, 頁 (始一終), 年/本文, 参照文献の数。

\section{Psychology}

\section{Psychological Abstracts}

(1) American Psychological Association (2) 1927 年 (3)月刊（1954～65 年は隔月刊) (4)心理学の他, 教育学, 社会学, 経済学, 言語学, 行動科学, マーケティング, 消 費者運動とかなり広い範囲にわたっている (5)単行書の 他，テクニカル レポート，政府刊行物などを収載して いる （6) 1974 年（51 52 巻） 25,558 件 (7) 6 10 か月 (8)報知的抄録，20\% 程度はごく簡単な指示的抄録 (9)著 者抄録が多い (10) a) 著者，主題 (Brief Subject Index; Thesaurus of Psychological Termsによる) b) Semi- 
Annual Index (Volume Index) 著者, 主題 (a) に同 じ) 別冊 (11) a) 873 誌 b) 563 (64.49\%), 63 (7.21\%), 73 (8.36\%), $174(19.93 \%)$ c) Index Volume に掲載 完全誌名 (12抄録番号, 著者, 所属, オリジナル・タイト ル, [英文タイトル], 雑誌名, 年, 月, 巻, 号, 頁 (始 一終), 本文 (抄録文中ですでに PA に収載された引用 文献はカッコ内に巻と抄録番号が付記されている), 抄録 の言語, 参照文献の数, 抄録者名 (13)各号に解説 (Key to the Text) が付いている。1967年より機械化され, MT データベースとなって Psychological Abstracts Information System を形成している。Index 類がいく つか出版されている。Author Index to Psychological Index 1894 1935, and Psychological Abstracts 1959 〜1963. 1960 5v.; Supplement 1. 1959 1963. 1965.; Cumulated Subject Index to Psychological Abstracts 1927 1960. 1966 2v. ; Cumulated Index to Psychological Abstract 1972 74. 1975 3v.

\section{Public Health}

\section{Abstracts on Hygiene}

(1) Bureau of Hygiene and Tropical Diseases (2) 1926 年, 1926 1967;Bulletin of Hygiene (3)月刊 (4)環境衛 生, Health Service, バクテリア, ウイルスによる疾病 （熱帯関係はのぞく）(5) Review, Report, 会議録を収載 している (6) 1974 年 4, 386 件 (7) $2 \sim 6$ か月 (8)報知的抄 録,ただしタイトルのみのものも多い(9第 3 者抄録が多 小 (10) a) 著者, 主題 b) 著者, 主題, Geographical Index (地理索引), 別冊 (11) a) 802 誌 b) 271 (33.79 \%), 108 (13.46\%), 84 (10.47\%), 339 (42.26\%) c) Supplement to Tropical Diseases Bulletin and Abstracts on Hygiene 1974 年, として出版された。また 50 巻 (1975 年) 1 号に揭載されている。(12)抄録番号, 著 者, オリジナル・タイトル, [英文タイトル], 雑誌名, 年, 巻, 号, 頁 (始一終), 本文, 抄録者名 (13)毎巻最終 号に Annual Review of World Literature が掲載され る。Bureau からは他に Tropical Diseases Bulletin が 出版されており, 熱帯医学に関するものは, こちらに収 載される。疾病よりは地理的条件が優先している。50 巻 (1975 年)よりセクションの分け方などが大きく変更 された。

\section{Smokin $_{r}$ and Health Bulletin}

(1) National Clearinghouse for Smoking and Health (2) 1964 年, 1964 年; Bibliography on Smoking and
Health, 1965 70年; Smoking and Health Bibliographical Bulletin (3)月刊 (4)契煙とその健康に及ぼす影響を, 化学, 薬学, また癌や消化器疾患, 行動科学, 教育学, 経済学などの面からみている (5) NIH レポート類を多 く含む，会議録を収載している (6) 1973 年 1, 342 件 1974

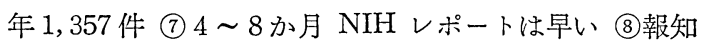
的抄録 (9)著者抄録が多い(10) a) 著者及び組織名索引, 主題 b) 年間で集積され Bibliography on Smoking and Health として出版されるが，その中に，著者および組 織名, 主題索引がある (11)収載誌リストなし, Technical Information Center of National Clearinghouse for Smoking and Health で所蔵するものが対象となってい る (12)抄録番号, 著者, オリジナル・タイトル, [英文タ イトル], 雑誌名, 巻, 号, 頁 (始一終), 年, 本文 (13) 月刊誌の他, 年間で集積されて Bibliography on Smoking and Health として出版されている。ただし出版は 遅れているよらである。

\section{Radiology}

Zentralblatt für die gesamte Radiologie

(1) Springer, Referatenorgan der Deutschen Röntgengesellschaft (2) 1926 年 (3)年に就よそ1巻，1巻は 6 冊で 6 冊目は Index (4)放射線医学, 治療 (5)単行書を 収載している（印を付し，各セクションの最初にきて いる) (9) 105 巻 (1974 年) 2,130 件 106 巻 (1974 75 年) 2,115 件 (7) 12 16 か月 (8)報知的抄録 (9)第3者抄録が 多小 (10) a) 著者 b) 著者, 主題, 出版は半年以上遅れる (11) a) 1, 207 誌うち国内誌 72 誌 b) 235 (19.46\%), 135 (11.18\%)，226(18.72\%)，611(50.62\%) c) 1971 年に 収載誌リストが出版された国別りスト (12)抄録番号，タ イトル, 著者, 所属, 雑誌名, 巻, 頁 (始一終), 年/本文 (独語), 抄録者名 (13) Springer からは他に 13 誌の抄録 誌が出版されている。本文でもいくつか紹介している。

\section{Surgery}

Zentralorgan für die gesamte Chirurgie und ihre Grenzgebiete

(1) Springer, in cooperation with the Deutsche Gesellschaft für Chirurgie (2) 1913 年 (3)年にほぼ 2 巻 1 巻は 6 冊で 6 冊目は Index (4)外科学 (5)単行書を収載し ている（印を付して各セクションの最初にきている） (6) 213 巻 (1974 年) 2,078 件, 214 巻(1974 年) 1,966 件 (7) 14 20 か月 8)報知的抄録 (9)著者抄録が多い(10) a) 
著者 b) 著者,主題 出版は $6 \sim 9$ か月遅れる (11 a) 821 誌 らち国内誌 46 誌 b) 149 (18.14\%), 96 (11.69\%), $142(17.29 \%), 434(52.86 \%)$ c) 1971 年に収载誌リス トが出版された，国別リスト (12抄録番号, タイトル, 著 者, 所属, 䧴誌名, 巻, 頁 (始一終), 年/本文(独語), 抄録者名, (13) Springer からは他に 13 誌の抄録誌が出版 されている。本文でも，いくつか紹介している。

\section{おわりに}

本文でとりあげるにあたっては，一応国内に数館以上 の所蔵館のあるもの，といら事を基準にした。また，あ る程度の資料も利用したが，実際に手にとって確認する という事を原則とした。本文が，主題別抄録誌を利用す る際の基礎的資料として利用されれば幸いである。また 同時に誤りを訂正し，不足を補っていただければなおさ らの事です。

煩雑な作業を快くひきうけて下さった方々，なかでも 東大医学図書館の早川氏には心から感謝いたします。

\section{参考文 献}

1. Morton, L. T.: Use of medical literature. Butterworths, 1974.

2. Medical reference works 1679 1966; a selected Bibliography. M. L. A., 1967.

Suppl. 1. M. L. A., 1970.

Suppl. 2, 1969 1972. M. L. A., 1973.

3. List of Journals indexed in Index Medicus. 1975.

4. Excerpta Medica List of Journals Abstracted 1975. Excerpta Medica, 1975.

（昭和 50 年 10 月 10 日受付）

付䘚：二次資料欄を持つ雑誌リスト

はじめに

大阪大学中之島図書館に括いて継続して受入れている 雑誌の中から，目についた範囲で集めてみた。タイトル に続いて，(1)発行頻度 (2)二次資料欄の名称，(3) 1974 年 の収載件数, (4)タイムラグ（計算方法は本文之同様）, (5)注釈, の順㲹記した。全体は, タイトルの ABC 順 とした。また, こうした欄はあっても, 収載件数の少い ものは, 省いた。

\section{American Journal of Ophthalmology}

(1)月刊 (2) Abstracts Department (3) 400 件 (4) $3 \sim 6$ か月。

\section{American Journal of Orthodontics}

(1)月刊 (2) Department of Reviews and Abstracts (3) 20 件 (4)抢そい ( 1 年以上) (5)抄録の他, 学位論文の 紹介，会議録の抄録などが揭載されている。

\section{American Journal of Public Health}

(1)月刊 (2) A Selected Public Health Bibliography with Annotation (3) 73 件 (4) 6 12 か月 (5)比較的短い 抄録で，年 2 回ほど揭載される。

American Journal of Roentgenology

(1)月刊 (2) Abstracts of Radiological Literatures (3) 240 件 (4) 6 12 か月

Annals of Allergy

(1)月刊 (2) Allergy Abstracts from Around the World (3) 300 件 (4) 8 12 か月

Annals of Otology, Rhinology and Laryngology

(1)隔月刊 (2) Abstracts of Current Articles (3) 29 件 (4)抢そい（ 1 年以上)

\section{Archives of Oral Biology}

(1)月刊 (2) Current Papers in Oral Biology (3) 125 件 (4) 5 12 か月 (5) 11 のセクションに分かれた, 雑誌記事 索引で, 基礎医学, 綜合誌などからも収載されている。

Blood

(1)月刊 (2) Abstracts (3) 480 件(4) 12 14 か月

\section{British Journal of Urology}

(1)隔月刊 (2)偶数号; Abstracts from Current Urological Literature, 奇数号; Current Urological Literature, Selected Bibliography (3)偶数号; 81 件，奇数号；2,000 件程度 (4) 10 か月程度 (5)奇数号は雑誌記事索引で, 20 以上のセクションに分れ Current Contents; Clinical Practice よりの引用である。

\section{Developmental Biology}

(1)月刊 (2) Current Literature (3) 1,900 件程度 (4) 3〜4か月 (5)雑誌記事索引で, いくつかのセクションに 分れている。セクション中は著者の $\mathrm{ABC}$ C順。

\section{Diabetes}

(1)月刊 (2) Abstracts (3) 223 件 (4) 6 10か月 (5)第 3 者の抄録の場合は長く, 詳しくなっている。

\section{Drugs}

(1)月刊 (2) Drug Literature Abstracts (3) 92 件 (4) 6〜10か月 (5)第 3 者抄録が多く詳しい。Lancet など, 総合誌からの抄録が多い。

\section{Gastroenterology}

(1)月刊 (2) Selected Summaries (3) 70 件 (4) $5 \sim 8$ か 
月 (5)第 3 者抄録で, コメントが付されている。 Geriatrics

(1)月刊 (2) Abstracts (3) 110 件 (4) 8 か月。 International Journal of Dermatology

(1)年 10 回 (2) Current Readings in World Literature Index (3) 722 件 (4) $2 \sim 6$ か月 (5) 13 巻 6 号 (74 年) よ り始った。College of Physicians (Philadelphia) の図 書館で所蔵する拈よそ 3,000 誌よりの記事索引で，いく つかのセクションに分けられている。

\section{Journal of Allergy and Clinical Immunology}

(1)月刊 (2) Allergy Abstracts (3) 118 件 (4) $5 \sim 8$ か 月 (5)第 3 者抄録でありかなり詳しい。

\section{JAMA}

(1)週刊 (2) Selected Abstracts (3) 3,435 件 (4) 0 4か 月 (5)雑誌のタイトルのもとに, いくつかの論文を選んで 抄録している。とくに AMA の雑誌のタイムラグが短 い。

\section{Journal of Chromatography}

(1)年 24 回 (2) Bibliography Section (3) 5, 483 件 (4) 10〜12 か月 (5)この部分が別ページ立てとなっており, 年間索引（著者, 主題及び Index of Types of Compounds Chromatographed) が付いている。記事索引。

\section{Journal of Histochemistry and Cytochemistry}

(1)月刊 (2) Histochemical Titles from Current Literature (3) 763 件 (4)9 12 か月 (5)毎回特定の編者が選び, 雑誌名のもとに論文名を記載している。

\section{Journal of Lipid Research}

(1)隔月刊 (2) New Methods (3) 326 件 (4) $8 \sim 9$ か月。 Journal of Oral Surgery

(1)月刊 (2) Current Literature (3) 185 件 (4) 4 9 מ 月 (5)第 3 者抄録。

\section{Journal of Pediatric Surgery}

(1)隔月刊 (2) International Abstracts of Pediatric Surgery (3) 365 件 (4) 6〜12 か月 (5) 12 のセクションに 分れている。第 3 者抄録。

\section{Journal of Periodontology}

(1)月刊 (2) Abstracts of Current Literature (3) 142 件 (4) 10 16 か月 (5)第 3 者抄録。

\section{Journal of Texture Studies}

(1)季刊 (2) Literature Abstracts (3) 91 件 (4)遅い (5) 5 つのセクションに分れている。Chemical Abstractsなど の他の抄録誌からも抄録している。

Journal of Trauma
(1)月刊 (2) Abstracts (3) 110 件 (4)遅い (5)毎号, 一人 のエデイターが行なって拈り,ヨーロッパのものが多い。 リプリントの請求先が記されている。

\section{Microscopia Acta}

(1)不定期，年 $5 \sim 6$ 回 (2) Berichte-Actual Information (3) 481 件 (4) 6 10 か月 (5)独語。第 3 者抄録

\section{Plastic and Reconstructive Surgery}

(1)月刊 (2) International Abstracts of Plastic and Reconstructive Surgery (3) 823 件 (4) $6 \sim 9$ か月 (5)第 3 者抄録。

Praxis de Pneumologie

(1)月刊 (2) Referate (3) 630 件 (4) $6 \sim 8$ か月 (5)独語。 第 3 者抄録。

\section{Radiology}

(1)月刊 (2) Abstracts of Current Literature (3) 1,045 件 (4) 8 10か月 (5) 5 つのセクションに分れ, 目次が各 号に付いている。第 3 者抄録。

\section{Surgery, Gynecology and Obstetrics}

(1)月刊 (2) International Abstracts of Surgery (3) 2,351 件 (4) 8 13 か月 (5) 13 のセクションに分れ，各号 に目次が付いている。第 3 者抄録。

\section{Transfusion}

(1)隔月刊 (2) Abstracts (3) 217 件 (4) 9 12 か月 (5)第 3 者抄録。

\section{Transplantation Proceedings}

(1)季刊 (2) Transplantation Proceedings Abstracts (3) 74 件 (4) 9 11 か月 (5)第 3 者抄録。

\section{Zahn-Mund Kifereheilkunde}

(1) 1974 年は 8 回 (2) Zentralbaltt (3) 2, 400 件程度 (4) 8〜12 か月 (5) 35 のセクションに分れ，指示的抄録が多 い。第 3 者抄録。

Zeitschrift fur Urologie und Nephrologie

(1)月刊 (2) Literatur Überscht (3) 1,634 件 (4) $7 \sim 10$ か月 (5)誌名のもとに論文を選んで索引している，記事 索引。

以上の他にも MEDLARS をデータベースとしたもの に次のようなものがある。

British Journal of Industrial Medicine.

Electroencephalography and Clinical Neurophysiology.

Journal of Medical Education.

Journal of Neurosurgery; Neurological BiblioIndex. 